\title{
Neurotransmitter patterns in patients with adolescent idiopathic scoliosis (AIS)
}

\author{
Mark Morningstar \\ From 10th International Conference on Conservative Management of Spinal Deformities - SOSORT 2013 \\ Annual Meeting \\ Chicago, IL, USA. 8-11 May 2013
}

\section{Background}

Central nervous system function is dependent upon neurotransmitters to properly integrate midbrain and cortical function. Central nervous system dysfunction is thought to be a primary driver of AIS progression.

\section{Purpose}

The goal of this study was to observe and analyze any patterns of imbalance in neurotransmitter status in patients with AIS.

\section{Methods}

The charts of 31 AIS patients from the same multidisciplinary medical center, ages 11-18, were reviewed and compared to a sampling of 31 patients without a history of scoliosis. Testing consisted of a urinalysis panel, analyzing 12 common neurotransmitters.

\section{Results}

Review of the completed urinalyses revealed a trend towards elevated histamine, elevated norepinephrine and decreased serotonin in the AIS patients as compared to non-scoliotics. Since these neurotransmitters are typically expressed in specific cortical areas, this pattern of imbalance may manifest as a functional hemisphericity, causing asymmetrical efferent responses to peripheral, afferent muscular inputs, and altering firing thresholds in their respective pathways.

\section{Conclusions and discussion}

4In the current sampling of patients with AIS, a trend toward specific neurotransmitter imbalances was observed. These imbalances may help shed light on the often-

Correspondence: drmorningstar@nwprc.com

Natural Wellness \& Pain Relief Center, Richmond, MI, USA observed somatosensory dyscoordination seen in this patient population.

Published: 18 September 2013

\section{References}

1. Marc DT, Ailts JW, Campeau DC, Bull MJ, Olson KL: Neurotransmitters excreted in the urine as biomarkers of nervous system activity: validity and clinical applicability. Neurosci Biobehav Rev 2011, 35(3):635-644.

2. Machida M, Dubousset J, Imamura Y, Miyashita Y, Yamada T, Melatonin Kimura J: A possible role in pathogenesis of adolescent idiopathic scoliosis. Spine 1996, 21(10):1147-1152.

3. Westermann J, Hubl W, Kaiser N, Salewski L: Simple, rapid, and sensitive determination of epinephrine and norepinephrine in urine and plasma by non-competitive enzyme immunoassay, compared with HPLC method. Clinical Laboratory 2002, 48:61-71.

doi:10.1186/1748-7161-8-S2-O1

Cite this article as: Morningstar: Neurotransmitter patterns in patients with adolescent idiopathic scoliosis (AIS). Scoliosis 2013 8(Suppl 2):O1.
Submit your next manuscript to BioMed Central and take full advantage of:

- Convenient online submission

- Thorough peer review

- No space constraints or color figure charges

- Immediate publication on acceptance

- Inclusion in PubMed, CAS, Scopus and Google Scholar

- Research which is freely available for redistribution
C Biomed Central

\section{Biomed Central}

(c) 2013 Morningstar; licensee BioMed Central Ltd. This is an Open Access article distributed under the terms of the Creative Commons Attribution License (http://creativecommons.org/licenses/by/2.0), which permits unrestricted use, distribution, and reproduction in any medium, provided the original work is properly cited. 